\title{
Prepoznava in preprečevanje izgorelosti
}

\author{
Sara Tement \\ Univerza $v$ Mariboru \\ sara.tement@um.si
}

Problematika izgorelosti je v zadnjem desetletju postala prepoznavna, pomembna in prevladujoča. Pričujoče poglavje predstavlja prikaz nekaterih dejavnikov izgorelosti in glavnih spoznanj o izgorelosti. Osredotoča se na prepoznavo izgorelosti in preventivo, vključno z nekaterimi najučinkovitejšimi metodami. V prvem delu se prispevek dotika obeh večjih perspektiv preučevanja: klinične in organizacijske. Klinična perspektiva zajema diagnostiko in identifikacijo osebnostnih dejavnikov izgorelosti, organizacijska pa se usmerja v preučevanje dejavnikov $\mathrm{v}$ delovnih okoljih ter intervencije znotraj delovnih organizacij. Prispevek v prvem delu navaja tudi opredelitve izgorelosti, potek in značilne simptome, ki jih je mogoče prepoznati pri tistih, ki poročajo o njej. Poglavje obsega tudi pregled dejavnikov izgorelosti z vidika značilnosti delovnih okoljih in z vidika osebnostnih lastnosti. Drugi del poglavja je namenjen kompetencam, ki jih psihologi potrebujejo za prepoznavo in preventivno delovanje na področju izgorelosti. Dodatno so predstavljene vaje za krepitev teh kompetenc $z$ namenom ohranjanja in izboljšanja lastnega duševnega zdravja ter duševnega zdravja svojih varovancev in drugih deležnikov. Omenjeno poglavje ozavešča psihologe in druge bralce o nastanku izgorelosti, prepoznavi ter uporabi omenjenega znanja v okviru preventive.

\section{Izhodišča}

Veliko zaposlenih bi se strinjalo, da so pogoste interakcije z drugimi ljudmi pri delu lahko napete in zahtevne. Tudi psihologi sodijo v skupino poklicev, ki so vsakodnevno soočeni z intenzivnim kontaktom z drugimi osebami. Nekateri takšne interakcije uspejo uspešno obvladovati, pri drugih pa je čez čas mogoče opaziti utrujenost, preobremenjenost, emocionalno praznino, občutke ujetosti in razočaranje nad delom. V slednji skupini posameznikov bomo pogosto našli tiste, ki so manj psihološko odporni, uporabljajo neučinkovite strategije spoprijemanja s stresom in verjamejo, da vsakodnevni dogodki v delovnem okolju in izven njega niso pod njihovim nadzorom (tj. zunanji lokus kontrole) (Alarcon idr., 2009). Njihovo počutje pa bodo dodatno zaostrili še drugi neugodni delovni pogoji, denimo časovni pritiski, nejasne delovne naloge in pomanjkanje nadzora nad delovnimi nalogami (Maslach idr., 2001). 
Preglednica 1 Znaki izgorelosti na individualni ravni

\begin{tabular}{llll}
\hline Čustveni znaki & Kognitivni znaki & Telesni znaki & Vedenjski znaki \\
\hline $\begin{array}{l}\text { Depresivno } \\
\text { razpoloženje }\end{array}$ & Brezupnost & Glavoboli & Hiperaktivnost \\
\hline $\begin{array}{l}\text { Spremembe v } \\
\text { razpoloženju }\end{array}$ & Izguba smisla & Motnje spanca & Impulzivnost \\
\hline $\begin{array}{l}\text { Emocionalna } \\
\text { otopelost }\end{array}$ & Občutki nemoči & Mišične bolečine & $\begin{array}{l}\text { Zloraba } \\
\text { psihoaktivnih } \\
\text { substanc }\end{array}$ \\
\hline Razdražljivost & Občutki krivde & Kronična utrujenost & Socialna izolacija \\
\hline Anksioznost & $\begin{array}{l}\text { Nezmožnost } \\
\text { koncentracije, } \\
\text { pozabljivost }\end{array}$ & $\begin{array}{l}\text { Gastrointestinalne } \\
\text { težave }\end{array}$ & $\begin{array}{l}\text { Pomanjkanje } \\
\text { motivacije }\end{array}$ \\
& & & \\
\hline
\end{tabular}

Nefunkcionalne osebnostne predispozicije in neugodne značilnosti dela predstavljajo potencialne dejavnike tveganja za pojav izgorelosti, stanja skrajne izčrpanosti, zmanjšane učinkovitosti in odtujenega odnosa do dela in vseh oseb, s katerimi so v interakcijah (Maslach idr., 2001). Avtorji poudarjajo še druge opredelitve izgorelosti, ki sta jim skupni izčrpanost na telesni, kognitivni in emocionalni ravni ter povezanost $\mathrm{z}$ delovnimi okoliščinami (npr. Bakker idr., 2014). V literaturi se pojav izgorelosti preučuje preko klinične perspektive, ki se osredotoča na diagnostiko in identifikacijo osebnostnih dejavnikov izgorelosti, ter organizacijske perspektive, ki poudarja pomen neugodnih delovnih pogojev pri nastanku izgorelosti. Iz obeh perspektiv pa izhajajo tudi različni preventivni ukrepi.

\section{Prepoznava izgorelosti in preventiva}

Izgorelost je mogoče prepoznati po več značilnih znakih na čustveni, kognitivni, vedenjski in telesni ravni, pri čemer ni nujno, da se pri posamezniku izrazijo vsi od navedenih znakov (Burisch, 2006; Schaufeli in Enzman, 1998).

Novejše študije kažejo, da se izgoreli posamezniki tudi pretirano negativno odzivajo na zavrnitve, kritike ali sodbe, ki jih doživljajo v medosebnih interakcijah (Bianchi idr., 2015b), so prekomerno pozorni na negativne dražljaje v primerjavi s pozitivnimi (Bianchi in Laurent, 2014) in imajo ruminativni slog razmišljanja (tj. pretirano premlevajo težave in tehtajo svoje odločitve) (Bianchi in Schonfeld, 2016; Košir idr., 2015). Pri razmišljanju o znakih izgorelosti najdemo pogost preplet med znaki stresa in depresivnosti, zato mnogi izpostavljajo težave pri obravnavi izgorelosti kot ločene duševne motnje (npr. Bianchi idr., 2015a; Tement idr., 2016). 
Nejasnosti pa se ne pojavljajo zgolj ob prepoznavi znakov izgorelosti, temveč tudi pri opredelitvi poteka izgorelosti (npr. Burisch, 2006). Raziskave $\mathrm{z}$ naprednimi vzdolžnimi raziskovalnimi načrti so denimo pokazale (npr. Taris idr., 2005), da je začetna faza izgorelosti neravnovesje med delovnimi zahtevami (tj. tistimi vidiki dela, ki zahtevajo nek napor) in delovnimi viri (tj. pozitivnimi vidiki dela, ki vodijo do povišane motivacije in omogočajo lažje soočanje $z$ obremenitvami). Takšno stanje vodi do izčrpanosti, ki onemogoča, da bi se popolnoma posvetili delu in vsem ljudem, vključenim vanj. $V$ zadnjem stadiju se začnemo takšnega odtujenega odnosa do dela zavedati in občutimo, da dela enostavno več ne moremo uspešno obvladovati ter smo pri njem manj učinkoviti. Vseeno pa vse več avtorjev poudarja, da napete interakcije pri delu in pretirana občutljivost nanje lahko privedejo do umika v medosebnih odnosih in od dela (Bianchi idr., 2015b; Taris idr., 2005), takšno stanje pa posledično privede do izčrpanosti. Večina avtorjev, med njimi tudi slovenski raziskovalci, se strinja, da je izgorelost kroničen in dolgoročen proces. A. Pšeničny (2006), denimo, predlaga, da se za začetne faze uporablja izraz izgorevanje, ki pa lahko sčasoma privede do psihofizičnega zloma oz. izgorelosti.

Skladno s procesnim razumevanjem izgorelosti je mogoče delovati preventivno in skušati zatreti njen nastanek ali pa se usmeriti v omejevanje razsežnosti težav. V prvo skupino ukrepov je mogoče umestiti primerno organizacijo dela (npr. odpravo nesmiselnih delovnih nalog in jasne opise delovnih nalog; Halbesleben in Buckley, 2004) in primerno selekcijo kadrov, ki utegneta prispevati k boljšemu ujemanju med značilnostmi zaposlenega in delovnimi pogoji (Maslach idr., 2001). V delovnih okoljih, ki delujejo po teh principih, bo verjetnost za nastanek izgorelosti manjša. Ko govorimo o ukrepih, ki so usmerjeni v ublažitev težav, pa je mogoče zaslediti takšne, ki so vezani na celotne delovne organizacije, in takšne, ki se osredotočajo na posameznika. Kombinacija obeh omenjenih skupin ukrepov, ki sicer temeljita na drugačnem razumevanju izgorelosti, pa je povezana $z$ najugodnejšimi učinki (Awa idr., 2010).

\section{Klinični pogled na izgorelost}

Izgorelost je mogoče razumeti kot individualno težavo, ki izhaja iz specifičnih individualnih in osebnostnih lastnosti. Klinični pogled nanjo pri tem zlasti poudarja naslednje dejavnike: visoko emocionalno labilnost in nizko stopnjo ekstravertnosti, zunanji lokus kontrole, nižje samospoštovanje (Alarcon idr., 2009), storilnostno pogojeno samovrednotenje (Pšeničny, 2006) in neučinkovite strategije spoprijemanja s stresom (Maslach 
idr., 2001). Tovrstno razumevanje se osredotoča na diagnostiko izgorelosti, svetovanje, individualno psihološko obravnavo in spremembo nefunkcionalnih osebnostnih lastnosti. Glavna težava, ki pa jo je ob tem mogoče zaslediti, je pomanjkanje jasnih diagnostičnih kriterijev. Izgorelosti ni mogoče zaslediti v Diagnostičnem in statističnem priročniku duševnih motenj (D S M-5) (American Psychiatric Association, 2013), v Mednarodni klasifikaciji bolezni (ICD-10) (World Health Organization, 1992) pa je zavedena pod težavami upravljanja z življenjem (z 73.o), zanjo pa je značilno stanje skrajne izčrpanosti. Tako na ravni simptomov kot na ravni obravnave je namreč pogosto zaznati preplet $\mathrm{z}$ depresijo, zlasti $\mathrm{z}$ atipično obliko depresije. Za slednjo so značilni utrujenost, pretirana ješčnost, razpoloženje, ki je odzivno na zunanje dogodke (torej tudi izboljšanje razpoloženja v luči pozitivnega dogodka), ter občutljivost na zavrnitve v medosebnih odnosih, vse navedeno pa močno ovira delovanje $\mathrm{v}$ delovnem ali drugih okoljih (Bianchi idr., 2015a). Jasno prepoznavo izgorelosti še dodatno ovira dejstvo, da težko ocenimo, kdo bi bil posebej ogrožen. Raziskave o spolnih in starostnih razlikah niso prinesle jasnih zaključkov. Nekateri avtorji ugotavljajo, da so mlajši zaposleni (Maslach idr., 2001) in ženske (Purvanova in Muros, 2010) dovzetnejši za izgorelost, hkrati pa opozarjajo, da so ugotovljene spolne in starostne razlike majhne.

Ukrepi za preprečevanje in obvladovanje izgorelosti so v okviru takšnega razumevanja izgorelosti izrazito vezani na posameznike. $V$ okviru klinične obravnave sta se $\mathrm{v}$ nekaterih redkih raziskavah pokazali kot učinkoviti kognitivno-vedenjska in analitična terapija (npr. Hochstrasser idr., 2016). $\mathrm{V}$ delovnih okoljih so bili izvedeni različni treningi in izobraževanja, cilj takšnih ukrepov pa je, da se posameznik nauči spoprijemati z obremenjujočimi okoliščinami (pri delu in $\mathrm{v}$ življenju nasploh) ali spremeni svoj odnos do dela. V. C. Hahn idr. (2011) so, denimo, razvile trening, v katerem so zaposlene izobrazile o tem, kako se odklopiti od dela, jih podučile o koristnih učinkih počitka po delu ter o ritualih za postavljanje meja med delom in zasebnim življenjem. Udeleženci treninga so sicer kazali zmanjšanje nekaterih znakov izgorelosti (npr. boljša kakovost spanca), niso pa nasploh poročali o nižji izgorelosti. Le Blanc in Schaufeli (2008) dodatno poročata o različnih treningih spoprijemanja s stresom (npr. izboljšanje asertivnosti v komunikaciji), ki so se pri izvajalkah zdravstvene nege pokazali kot učinkoviti pri preprečevanju znakov izgorelosti. Kljub določenim ugodnim učinkom pa metaanalize kažejo, da tovrstni individualni pristopi niso dolgoročno učinkoviti (Awa idr., 2010), ugodni učinki pa največkrat ne trajajo več kot 6 mesecev. Njihovo prednost pa zaznavajo zlasti delodajalci in vo- 
dilni, ki skrb za lastno blagostanje ob delu v celoti prenašajo na zaposlenega.

\section{Organizacijski pogled na izgorelost}

Izgorelost je mogoče razumeti tudi kot rezultat neugodnih delovnih okoliščin. V okviru organizacijskega pogleda na izgorelost je mogoče zaslediti stališče, da individualni dejavniki igrajo manj pomembno vlogo pri nastanku izgorelosti kot dejavniki na delovnem mestu (Maslach idr., 2001). Večje število raziskav je potrdilo domnevo, da k izgorelosti prispevajo zlasti delovne zahteve, kot so: nejasno definirane delovne naloge, previsoke zahteve dela, časovni pritiski, konfliktni vidiki dela (tj. neskladje med zahtevami, pričakovanji na delovnem mestu) in emocionalne zahteve dela (tj. napor, povezan $\mathrm{z}$ upravljanjem emocij $\mathrm{v}$ medosebnih interakcijah) (npr. Alarcon, 2011; Bakker idr., 2014). Dodaten dejavnik tveganja predstavlja tudi pomanjkanje delovnih virov, ki predstavljajo tiste značilnosti dela, ki omogočajo uspešno soočanje $z$ delovnimi zahtevami ter spodbujajo rast, razvoj in motivacijo zaposlenih (Bakker in Demerouti, 2007). Med takšnimi dejavniki najdemo oporo s strani nadrejenih in s strani sodelavcev, svobodo odločanja/avtonomnost na delovnem mestu (tj. stopnja, do katere lahko zaposleni samostojno načrtuje svoje delo), raznolikost, celovitost (tj. stopnja, do katere posameznikovo delo zahteva izdelavo celotnega delovnega procesa ali odseka dela) in pomembnost delovnih nalog, povratne informacije na delovnem mestu ter gotovost zaposlitve.

Pomembno spoznanje, ki sledi iz te skupine raziskav, je, da je pri preprečevanju izgorelosti pomembno zmanjševanje delovnih zahtev in povečevanje delovnih virov. Večina organizacijskih intervencij vsebuje enega ali oba elementa. Cilj takšnih ukrepov znotraj delovnih organizacij je v tem, da se spremeni obremenjujoče in zdravju škodljivo okolje in pogosto tudi način izvedbe delovnih nalog. $V$ enem izmed takšnih ukrepov za izvajalce zdravstvene nege na onkološkem oddelku so s pomočjo predlogov in vključitve samih udeležencev $\mathrm{v}$ načrtovanje sprememb prispevali $\mathrm{k}$ izboljšavam pri organizaciji dela ter zagotavljanju večje količine opore in povratnih informacij (s pomočjo rednih sestankov) (Le Blanc idr., 2007). Omenjena intervencija je prispevala $k$ zmanjšanju izčrpanosti in odtujenega odnosa tudi do več mesecev po intervenciji. $V$ ta sklop intervencij sodi tudi trening vodilnih, ki lahko s svojim vsakodnevnim ravnanjem bistveno posežejo v rutino zaposlenih in jih zavarujejo pred resnimi posledicami. Takšen trening je lahko usmerjen $v$ prepoznavanje znakov izgorelosti zaposlenih in pomoč pri iskanju rešitev za takšne zaposlene ter načrtovanje konkretnih ukre- 
pov (Borza idr., 2012). Dolgoročni učinki takšnega treninga na izgorelost se sicer niso pokazali, čeprav Le Blanc in Schaufeli (2008) ugotavljata, da sta prav vključitev in podpora vodilnih ključna za uspešnost organizacijskih intervencij. V kolikor so bile takšne intervencije uspešno izvedene, so se pokazale za uspešnejše pri preprečevanju izgorelosti kot individualno usmerjene intervencije in so prinesle tudi vrsto drugih pozitivnih učinkov (npr. povečano pripadnost organizaciji; Awa idr., 2010).

\section{Kompetence za prepoznavo in preprečevanje izgorelosti}

Prisotnost izgorelosti lahko močno okrni sposobnost psihologov za kakovostno opravljanje svojega dela. Starejša študija avtorjev Ackerleyja idr. (1988) je pokazala, da tudi do ena tretjina psihologov poroča o visokih stopnjah emocionalne izčrpanosti in odtujenega odnosa do dela in do klientov. Posebno rizično skupino predstavljajo mladi psihologi, ki so predani svojemu delu ter katerih delo vključuje obravnavo mnogih klientov s težavami na področju duševnega zdravja. Narava težav klientov prav tako predstavlja možen dejavnik, saj psihologi, ki obravnavajo žrtve zlorab ali nasilja, poročajo o večjih stopnjah izgorelosti. Večje razlike v stopnji izgorelosti se kažejo med psihologi, ki delajo v zasebnih zavodih, in tistimi, ki so zaposleni v javnem sektorju (Rupert in Morgan, 2005). Predvideva se, da so glavni razlogi za nastale razlike manj nadzora pri delu in več administrativnih opravil $v$ javnih zavodih pa tudi razlike $v$ plačilu. Raziskave na vzorcu psihologov dodatno kažejo, da izčrpanost pri delu vodi do nižjega družinskega zadovoljstva (Rupert idr. 2013). Omenjeno utegne še zaostrovati počutje psihologov, saj njihove težave z izgorelostjo onemogočajo črpanje virov opore in razpoloženja iz družinskega okolja. Ohranjanje in pridobivanje različnih varoval je za poklic psihologa še posebej pomembno, saj je skrb za lastno duševno zdravje in kritično razmišljanje o njem ključni element njegove strokovne usposobljenosti. Omenjeni razmislek je zajet tudi v različne etične kodekse psihologov. Posebej pomemben je na tem mestu sledeči člen: »Psiholog prevzema in opravlja strokovno delo, kadar mu telesno in psihično zdravje dovoljuje in omogoča poklicno zmožnost in presojo« (Društvo psihologov Slovenije, 2018, str. 10).

Psihologom pri obvladovanju izgorelosti in posledično vzdrževanju strokovne usposobljenosti utegnejo pomagati različne aktivnosti in vaje $(\mathrm{Ru}-$ pert in Kent, 2007; Skovholt in Trotter-Mathison, 2016; Stevanovic in Rupert, 2004), ki so navedene v nadaljevanju. Vsaka izmed predvidenih aktivnosti krepi specifične kompetence in znanja. V nadaljevanju poglavja je vsaka aktivnost tudi podrobneje predstavljena. 
Preglednica 2 Pregled aktivnosti ter ključnih kompetenc in znanj za področje izgorelosti

\begin{tabular}{ll}
\hline Znanja & Kompetence \\
\hline - Samoocena izgorelosti & - Krepitev samorefleksije in zavedanje dejavnikov tveganja \\
- Zaznavanje tveganih & - Soustvarjanje pozitivnega delovnega okolja in nudenje \\
delovnih pogojev & pomoči drugim sodelavcem \\
- Preoblikovanje delovnih & $\begin{array}{l}\text { - Vzdrževanje ravnotežja med skrbjo za druge osebe in } \\
\text { pogojev } \\
\end{array}$ \\
& skrbjo zase ter med delovnim in zasebnim življenjem \\
& - Sprememba perspektive in identifikacija pozitivnih \\
& vidikov dela \\
\hline
\end{tabular}

\section{Samoocena izgorelosti}

$\mathrm{V}$ tuji in slovenski literaturi se za proučevanje izgorelosti in delno tudi za individualno diagnostiko najpogosteje uporablja Maslach Burnout Inventory (Maslach idr., 1996), ki ima več različic. Za psihologe je posebej primerna verzija M B I-Human Services Survey, ki pa je, tako kot druge verzije, avtorsko zaščitena in jo je mogoče naročiti zgolj pri založniku. V zadnjih letih so v slovenskem jeziku na voljo tudi drugi instrumenti (npr. Oldenburg Burnout Inventory; Sedlar idr., 2015), ki pa nimajo najprimernejših merskih značilnosti. Za namene krepitve samorefleksije in zavedanja lastne ogroženosti je lahko v oporo že niz spodnjih vprašanj. V primeru pritrdilnih odgovorov na večino trditev je priporočljivo, da se reši katerega izmed omenjenih instrumentov, ki imajo tudi uveljavljene mejne vrednosti, po katerih je mogoče oceniti natančno razsežnost znakov izgorelosti.

\section{Aktivnost}

S pomočjo spodnjih vprašanj razmislite o svojem delu in počutju po delu v zadnjem letu.

1. Ste se pogosto počutili preobremenjeni $z$ delovnimi obveznostmi?

2. Ste se pogosto počutili telesno izčrpani, brez energije in izžeti?

3. Ste se pogosto počutili kognitivno in emocionalno izčrpani?

4. Ste bili pogosto utrujeni že pred začetkom dela in med delom?

5. Ste se pogosto zalotili, da ste nekoliko brezbrižni do klientov?

6. Ste se pogosto počutili nekompetentno in neučinkovito?

7. Ste se pogosto zavedali, da vam delo več ne predstavlja veselja?

\section{Zaznavanje tveganih delovnih pogojev}

Obvladovanje izgorelosti pomeni tudi zavedanje lastnih delovnih zahtev in virov ter hkrati prepoznavanje delovnih zahtev in virov pri sodelavcih. De- 
lovne zahteve so vsi fizikalni, psiho-socialni in organizacijski vidiki dela, ki zahtevajo trajni telesni in/ali mentalni napor ter posledično terjajo določen psihološki in/ali fiziološki davek (Bakker in Demerouti, 2007; Tement in Korunka, 2013). Primeri zahtev so časovni pritiski ali konfliktni vidiki dela. Delovne vire pa lahko opredelimo kot vse fizikalne, psiho-socialne in organizacijske vidike dela, ki pomagajo pri doseganju delovnih ciljev, ki zmanjšujejo zahteve dela in posledično njihove negativne posledice ter ki spodbujajo osebnostno rast, učenje in razvoj (Bakker in Demerouti, 2007; Tement in Korunka, 2013); primera sta opora s strani sodelavcev in svoboda odločanja pri delu. Pričujoč vprašalnik je namenjen oceni nekaterih delovnih zahtev in virov pri delu psihologa. Mogoče ga je uporabiti tudi pri sodelavcih in jim ponuditi povratno informacijo glede njihovega dela.

\section{Aktivnost}

V nadaljevanju je podanih 12 trditev, ki se nanašajo na različne vidike vašega dela. Prosim, da vsako trditev pazljivo preberete in ocenite, kako pogosto se posamezen vidik pojavlja pri vašem delu. Če še nikoli niste občutili določenega vidika dela, ga ocenite $\mathrm{z}$ nič. Če ste opisan vidik že doživeli, pa $z$ ena do šest ocenite, kako pogosto ga doživljate.

a Pri delu lahko samostojno sprejemam veliko odločitev.

$b$ Moji sodelavci so mi pripravljeni pomagati.

c Pri delu se srečujem s čustveno nabitimi situacijami.

$d$ Moje delo zahteva valiko zbranosti.

e Moji sodelavci so pripravljeni prisluhniti mojim težavam.

$f$ Moje delo je miselno naporno.

$g$ Pri delu se soočam s stvarmi, ki se me osebno dotaknejo.

$h$ Moji sodelavci so mi občasno pripravljeni odvzeti nekaj delovnih na$\log$.

i Pri delu lahko pogosto odločam o tem, katere delovne naloge bom opravil/-a.

j Moje delo je emocionalno zahtevno.

$k$ Pri delu lahko pogosto odločam o tem, kako bom opravil/-a delovne naloge.

$l$ Moje delo zahteva povečano skrb in natančnost.

Pomen ocen: o - nikoli, 1 - nekajkrat letno ali manj, 2 - enkrat mesečno ali manj, 3 - nekajkrat mesečno, 4- enkrat tedensko, 5 - nekajkrat tedensko, 6 - vsak dan. 

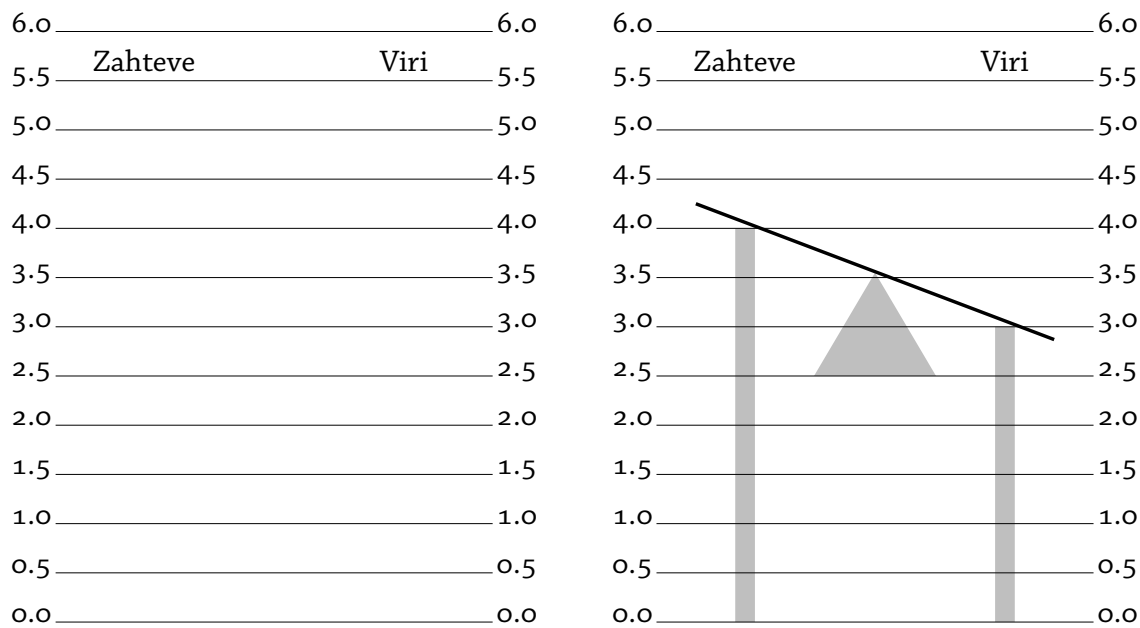

Slika 1 Grafični prikaz delovnih zahtev in virov

Vprašalnik se vrednoti na sledeč način:

- Emocionalne zahteve $=(c+g+j) / 3$.

- Kognitivne zahteve $=(d+f+l) / 3$.

- Delovne zahteve (povprečje) $=(c+g+j+d+f+l) / 6$.

- Nadzor nad delom $=(a+i+k) / 3$.

- Opora s strani sodelavcev $=(b+e+h) / 3$.

- Delovni viri (povprečje) $=(a+i+k+b+e+h) / 6$.

Dobljeni povprečji delovnih zahtev in virov vnesite v predlogo (slika 1 levo) tako, da narišete stolpec za delovne zahteve in stolpec za delovne vire. Oba stolpca povežite $\mathrm{z}$ ravno črto in risbi dodajte trikotnik, ki podpira ravno črto. Končna slika bo spominjala na uravnoteženo oz. neuravnoteženo tehtnico (slika 1 desno).

Ob reševanju vprašalnika lahko dodatno razmislite o tem, ali pri svojem delu zaznavate še kakšne zahteve in vire.

\section{Preoblikovanje delovnih pogojev}

V literaturi je v zadnjih letih mogoče zaslediti koncept preoblikovanja dela (angl.job crafting) (Tims idr., 2012; Wrzesniewski in Dutton, 2001), ki označuje samoiniciativno spremembo vedenja zaposlenih $\mathrm{z}$ namenom usklajevanja dela z njihovimi preferencami in motivi. A. Wrzesniewski in J. E. Dutton (2001) navajata naslednje vidike dela, ki jih je mogoče spremeniti preko 
samoiniciativnih vedenj: določene vidike delovnih nalog (vsebine, obseg), odnose na delovnem mestu in svoj odnos do dela ter vidike zasebnega življenja, ki omogočajo bolj zdravo ravnotežje med delom in zasebnim življenjem (iz angl. work-family balance crafting).

Zaposleni se v uporabi tovrstnih vedenjskih strategij precej razlikujejo, jasno pa je, da tisti, ki ohranjajo aktiven odnos do dela in delovnih nalog, poročajo o manjšem številu znakov izgorelosti. Čeprav so tovrstna vedenja do določene mere pogojena $\mathrm{z}$ osebnostnimi lastnostmi, se jih je mogoče naučiti in uporabiti pri lastni delovni situaciji (van den Heuvel idr., 2015).

Vsak izmed nas pri svojem delu (ne glede na naravo dela) lahko najde nove in zanimive vidike, spremeni svoj pogled na delo, preoblikuje zadolžitve ali skrbi za kakovostne odnose. Vse od navedenega lahko krepi naše delovne vire, zmanjšuje zahteve ter nasploh služi kot preventiva pri izgorelosti. Pomemben varovalni dejavnik pri izgorelosti so tudi kakovostni zasebni odnosi, pester nabor prostočasnih aktivnosti in miselni odklop od dela. Spremembe na tem nivoju prav tako utegnejo prispevati k ugodnejšemu počutju pri delu.

\section{Aktivnost}

Razmislite o vsakem vidiku preoblikovanja (dela) in zapišite, kako bi lahko ta vidik pri vašem delu in v zasebnem življenju udejanjili. Zastavite si lasten načrt preoblikovanja s pomočjo S M A R T-načela postavljanja ciljev (če je to mogoče) in razmislite o morebitnih ovirah.

SMART-postavljanje ciljev:

S (Specific) - cilji morajo biti točno določeni in jasno definirani.

M (Measurable) - cilji morajo biti merljivi in izraženi v številčni obliki.

A (Action-Oriented) - cilji se morajo nanašati na neko konkretno dejanje, ki ga lahko opravimo, da bomo bližje cilju.

$\mathrm{R}$ (Realistic) - cilji morajo biti realistični in nekje med izzivi ter dosegljivostjo.

T (Time Bound) - vsi cilji morajo imeti nek »deadline« oz. datum zaključka

Primer: »Od jutri naprej bom svoje delo začela s pozitivnejšo naravnanostjo in bom bolj hvaležna zanj.«

1. Spremembe v nalogah (task crafting; Wrzesniewski in Dutton, 2001): spremembe v vsebini, količini ali vrsti nalog. Kako bi ta vidik lahko 
upoštevali pri vašem delu? Na kakšne ovire bi lahko naleteli? Kako bi ovire lahko premostili?

2. Spremembe v medosebnih odnosih (relational crafting; Wrzesniewski in Dutton, 2001): spremembe v načinu komunikacije in v pogostosti interakcij; načrtna izbira oseb, s katerimi komuniciramo. Kako bi ta vidik lahko upoštevali pri vašem delu? Na kakšne ovire bi lahko naleteli? Kako bi ovire lahko premostili?

3. Spremembe v odnosu do dela (cognitive crafting; Wrzesniewski in Dutton, 2001): spremembe v pogledu na lastne delovne naloge; spremembe v pomenu, ki ga pripisujemo nalogam. Kako bi ta vidik lahko upoštevali pri vašem delu? Na kakšne ovire bi lahko naleteli? Kako bi ovire lahko premostili?

4. Spremembe v zasebnem okolju (work-family balance crafting): načrtovanje časa za družino/za prijatelje/zase; vzdrževanje meja med delom in zasebnim okoljem; spremembe v preživljanju prostega časa (npr. redna telesna vadba); spremembe v komunikaciji izven dela (npr. iskanje opore); postavljanje prioritet. Kako bi ta vidik lahko upoštevali $\mathrm{v}$ vašem življenju/prostem času? Na kakšne ovire bi lahko naleteli? Kako bi ovire lahko premostili?

\section{Zaključek}

Vsak zaposleni se pri delu občasno počuti utrujeno in razočarano. Izgorelost predstavlja skrajno razsežnost takšnih občutij, ki nas močno ovira pri opravljanju dela in vsakodnevnem delovanju. $V$ okviru prepoznave izgorelosti in preventive je pomembno, da se zavedamo znakov izgorelosti, možnega poteka ter rizičnih dejavnikov. Prepoznava izgorelosti in preventivno delovanje sta še posebej pomembni za psihologe, katerih duševno zdravje je tesno povezano z ravnjo njihove strokovne usposobljenosti. Psihologom lahko pri ohranjanju duševnega zdravja in ublažitvi znakov izgorelosti pomagajo že samorefleksija lastne situacije, zavedanje rizičnih delovnih dejavnikov in usmeritve za spremembo določenih delovnih pogojev. Navedene aktivnosti imajo lahko pozitivne posledice za psihologe, njihove varovance in sodelavce ter so ključnega pomena zlasti ob odsotnosti organizacijskih dejavnikov, ki bi zagotavljali zdrava delovna okolja.

\section{Literatura}

Ackerley, G. D., Burnell, J., Holder, D. C., in Kurdek, L. A. (1988). Burnout among licensed psychologists. Professional Psychology: Research and Practice, 19(6), 624-631. 
Alarcon, G. M. (2011). A meta-analysis of burnout with job demands, resources, and attitudes. Journal of Vocational Behavior, 79(2), 549-562.

Alarcon, G., Eschelman, K. J., in Bowling, N. A. (2009). Relationships between personality variables and burnout: A meta-analysis. Work \& Stress, 23(3), 244-263.

American Psychiatric Association. (2013). Diagnostic and statistical manual of mental disorders (5. izdaja).

Awa, W. L., Plauman, M., in Walter, U. (2010). Burnout prevention: A review of intervention programs. Patient Education and Counseling, 78(2), 184190.

Bakker, A. B., in Demerouti, E. (2007). The job demands-resources model: State of the art. Journal of Managerial Psychology, 22(3), 309-328.

Bakker, A. B., Demerouti, E., in Sanz-Vergel, A. I. (2014). Burnout and work engagement: The J D-R approach. Annual Review of Organizational Psychology and Organizational Behavior, 1(1), 389-411.

Bianchi, R., in Laurent, E. (2015). Emotional information processing in depression and burnout: An eye-tracking study. European Archives of Psychiatry and Clinical Neuroscience, 265(1), 27-34.

Bianchi, R., in Schonfeld, I. S. (2016). Burnout is associated with a depressive cognitive style. Personality and Individual Differences, 100, 1-5.

Bianchi, R., Schonfeld, I. S., in Laurent, E. (2015a). Burnout-depression overlap: A review. Clinical Psychology Review, 36, 28-41.

Bianchi, R., Schonfeld, I. S., in Laurent, E. (2015b). Interpersonal rejection sensitivity predicts burnout: A prospective study. Personality and Individual Differences, 75, 216-219.

Borza, A., Tement, S., Zdrehus, C., in Korunka, C. (2012). The B o I training: An overview of a burnout intervention and initial survey results. Procedia: Social and Behavioral Sciences, 33, 223-227.

Burisch, M. (2006). Das Burnout-Syndrom: Theorie der inneren Erschöpfung. Springer Medizin Verlag.

Društvo psihologov Slovenije. (2018). Kodeks poklicne etike psihologov Slovenije. http://www.dps.si/wp-content/uploads/2018/o6/KPE_2018.pdf

Hahn, V. C., Binnewies, C., Sonnentag, S., in Mojza, E. J. (2011). Learning how to recover from job stress: Effects of a recovery training program on recovery, recovery-related self-efficacy, and well-being. Journal of Occupational Health Psychology, 16, 202-216.

Halbesleben, J. R. B. in Buckley, M. R. (2004). Burnout in organizational life. Journal of Management, 30, 859-879.

Hochstrasser, B., Brühlmann, T., Cattapan, K., Hättenschwiler, J., HolsboerTrachsler, E., Kawohl, W., Schulze, B., Seifritz, E., Schaufeli, W., Zemp, A., in Keck, M. W. (2016). Burnout-Behandlung Teil 1: Grundlagen. Schweizerisches Medizin-Forum, 16(2), 538-541. 
Košir, K., Tement, S., Licardo, M., in Habe, K. (2015). Two sides of the same coin? The role of rumination and reflection in elementary school teachers' classroom stress and burnout. Teaching and Teacher Education, 47, 131-141.

Le Blanc, P. M., Hox, J. J., Schaufeli, W. B., Taris, T. W., in Peeters, M. C. W. (2007). Take care! The evaluation of a team-based burnout intervention program for oncology care providers. Journal of Applied Psychology, 92(1), 213-227.

Le Blanc, P. M., in Schaufeli, W. B. (2008). Burnout intervention: An overview and illustration. V J. R. B. Halbesleben (ur.), Handbook of stress and burnout in health care (str. 201-215). Nova Science Publishers.

Maslach, C., Jackson, S. E., in Leiter, M. P. (1996). M BI: The Maslach burnout inventory manual (3. izdaja). Consulting Psychologists Press.

Maslach, C., Schaufeli, W. B., in Leiter, M. P. (2001). Job burnout. Annual Review of Psychology, 52, 397-422.

Pšeničny, A. (2006). Recipročni model izgorelosti (RMI): Prikaz povezave med interpersonalnimi in intrapersonalnimi dejavniki. Psihološka obzorja, 15(3), 19-36.

Purvanova, R. K., in Muros, J. P. (2010). Gender differences in burnout: A meta-analysis. Journal of Vocational Behavior, 77(2), 168-185.

Rupert, P. A., Hartman, E., in Miller, A. (2013). Work demands and resources, work-family conflict, and family functioning among practicing psychologists. Professional Psychology: Research and Practice, 44(5), 283-289.

Rupert, P. A., in Kent, J. S. (2007). Gender and work setting differences in career-sustaining behaviors and burnout among practicing psychologists. Professional Psychology: Research and Practice, 38(1), 88-96.

Rupert, P. A., in Morgan, D. J. (2005). Work setting and burnout among professional psychologists. Professional Psychology: Research and Practice, 36(5), 544-550.

Schaufeli, W. B., in Enzmann, D. (1998). The burnout companion to study and research: A Critical analysis. Taylor \& Francis.

Sedlar, N., Šprah, L., Tement, S., in Sočan, G. (2015). Internal structure of an alternative measure of burnout: Study on the Slovenian adaptation of the Oldenburg Burnout Inventory (O L B I). Burnout Research, 2(1), 1-7.

Skovholt, T. M., in Trotter-Mathison, M. (2016). The resilient practitioner: Burnout prevention and self-care strategies for counselors, therapists, teachers, and health professionals (3. izdaja). Routledge.

Stevanovic, P., in Rupert, P. A. (2004). Career-sustaining behaviors, satisfactions and stresses of professional psychologists. Psychotherapy: Theory, Research, Practice, Training, 41(3), 301-309.

Taris, T. W., Le Blanc, P. M., Schaufeli, W. B., in Schreurs, P. J. G. (2005). Are there causal relationships between the dimensions of the Maslach 
Burnout Inventory? A review and two longitudinal tests. Work \& Stress, 19(3), 241-258.

Tement, S., in Korunka, C. (2013). Does trait affectivity predict work-tofamily conflict and enrichment beyond job characteristics? Journal of Psychology: Interdisciplinary and Applied, 147(2), 197-216.

Tement, S., Jaušovec, N., in Pahor, A. (2015). E E G correlates of burnout and depression among students: The role of gender. Biological Psychology, 114, 1-12.

Tims, M., Bakker, A. B., in Derks, D. (2012). The development and validation of the job crafting scale. Journal of Vocational Behavior, 80(1), 173-186.

Van den Heuvel, M., Demerouti, E., in Peeters, M. C. W. (2015). The job crafting intervention: Effects on job resources, self-efficacy, and affective well-being. Journal of Occupational and Organizational Psychology, 88(3), 511-532.

World Health Organization. (1992). The ICD-10 classification of mental and behavioural disorders: Clinical descriptions and diagnostic guidelines.

Wrzesniewski, A., in Dutton, J. E. (2001). Crafting a job: Revisioning employees as active crafters of their work. Academy of Management Review, 26(2), 179-201.

\section{Recognition and Prevention of Burnout}

In the past decades, burnout has gained visibility and relevance but has also become more prevalent. This chapter strives to provide a comprehensive overview of the burnout syndrome. First, it focuses on burnout recognition and prevention including some of the most efficient prevention methods. In the first part, this contribution describes the two major perspectives of studying burnout. The clinical perspective includes burnout diagnostics and identification of personality antecedents of burnout, whereas the organizational perspective turns its attention to studying burnout antecedents in working environments and burnout interventions at organizational level. This part of chapter also includes burnout definitions, the burnout process, and characteristic symptoms. A review of burnout antecedents in terms of work characteristics and personality is provided as well. The second part of the chapter is directed towards competencies, which psychologists need for recognizing and preventing burnout. It additionally introduces exercises for building these competencies in order to preserve and strengthen one's own mental health and the mental health of one's mentees and other stakeholders. After studying this chapter, the reader should be able to understand the emergence of burnout, to recognize burnout signs and to apply this knowledge to the context of prevention. 